\title{
Recession of Yanamarey Glacier in Cordillera Blanca, Peru, during the 20th century
}

\author{
Stefan Hastenrath \\ Department of Atmospheric and Oceanic Sciences, University of Wisconsin-Madison, 1225 West Dayton Street, Madison, \\ Wisconsin 53706, U.S.A. \\ Alcides Ames \\ Unidad de Glaciologia e Hidrología, Electroperu, Huaraz, Peru
}

\begin{abstract}
For Yanamarey Glacier in Cordillera Blanca, Peru, mostly situated between about 5000 and $4600 \mathrm{~m}$, maps of the surface topography at a scale of $1: 5000$ obtained by terrestrial triangulation for 1973, 1982 and 1988 and by aerial photogrammetry for 1948 and 1962 are compared with the glacier boundaries from a 1939 map and an undated maximum extent inferred from moraine morphology. The glacier length decreased from the maximum, $2800 \mathrm{~m}$ to $1600 \mathrm{~m}$ in 1948 , and to $1250 \mathrm{~m}$ in 1988 , with an accompanying decrease in area from $17 \times 10^{5}$ to $10 \times 10^{5}$ and thence to $8 \times 10^{5} \mathrm{~m}^{2}$. The shrinkage of ice volume was $35 \times 10^{6} \mathrm{~m}^{3}$ from the maximum to 1948 , and $29 \times 10^{6} \mathrm{~m}^{3}$ from 1948 to 1988 , compared to a total remaining ice volume of about $25 \times 10^{6} \mathrm{~m}^{3}$ in 1988 . This quantitative assessment of mass-loss rates creates the observational basis for sensitivity studies of the climatic forcing.
\end{abstract}

\section{INTRODUCTION}

Glaciers in the high mountains of the tropics merit attention in the context of global change. Monitoring and documentation efforts at the international level (Haeberli and Hoelzle, 1993; Haeberli and others, 1993) bear out the dearth of information especially for the tropical half of the Earth. Successive reconstructions have, however, afforded a general overview of secular glacier variations in the low latitudes. Thus, in East Africa, glaciers began to recede after 1880 , as evidenced by a combination of field observations, expedition reports and numerical modeling (Hastenrath, 1984; Kruss, 1984). For New Guinea (Hope and others, 1976), Allison and Kruss (1977) deduced from numerical modeling an onset of glacier recession around 1850. For the Ecuadorian Andes, evaluation of historical sources (Hastenrath, 1981) indicates a gradual rise of the ice-equilibrium line since at least the middle of the 19th century. For the most recent decades, continuing decrease of the ice-covered area has been reported in the Venezuelan Andes (Schubert, 1992), and accelerated volume loss has been measured on the largest outlet glacier of the Quelccaya Ice Cap of southern Peru (Brecher and Thompson, 1993).

With this background, the Cordillera Blanca of northern Peru (Fig. 1) merits particular attention, because it was the object of a systematic glacier inventory and mapping in the 1930s (Kinzl, 1942, 1949, 1964) and of later work by the Unidad de Glaciología e Hidrología, Electroperu (Ames and others, 1988; Kaser and others, 1990). Glaciological monitoring by Electroperu in the
1970 s and 1980 s included repeated terrestrial mapping of surface topography and ice extent of Yanamarey Glacier in the Cordillera Blanca. For 1962 and 1948 it proved

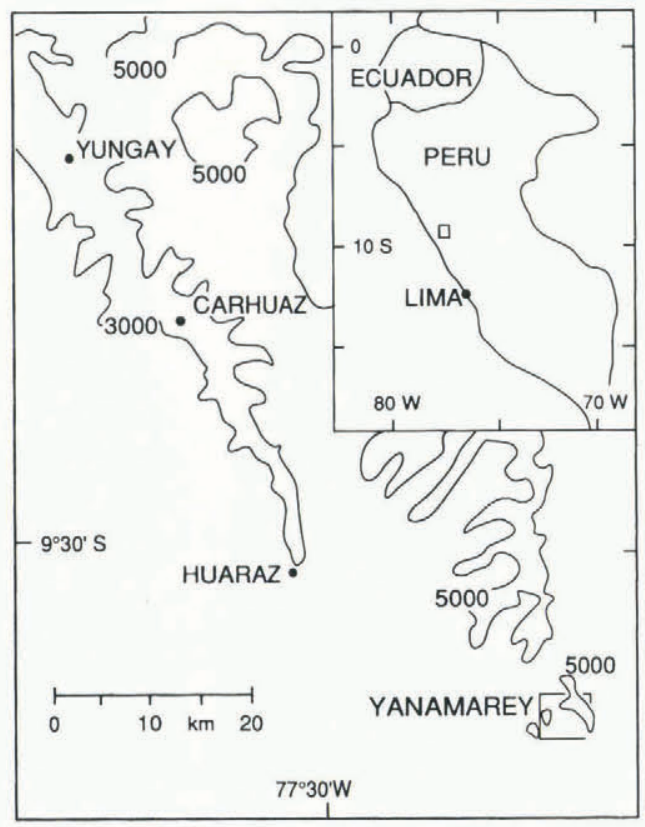

Fig. 1. Orientation map of Cordillera Blanca with height contours of 3000 and $5000 \mathrm{~m}$; scale 1:1000000. Rectangle in southeast corner indicates area of Tanamarey Glacier in Figure 2. Insert in upper-right corner shows location of Cordillera Blanca within Peru. 
possible to map the surface topography of this glacier from historical air photography. In addition, ice boundaries could be traced for the 1930s from an expedition account (Kinzl, 1942, 1964), and for a maximum extent from large moraines. In the present paper, this diverse evidence is compiled and evaluated to reconstruct the length, area and volume changes of Yanamarey Glacier over much of the past century. This is motivated by the need for quantitative information for analysis of the climatic forcing.

\section{THE MAPPINGS}

Information of varied detail and quality is available for seven dates: an undated maximum extent indicated by moraines, and May-August 1939, 31 August 1948, 17 June 1962, 10 May 1973, 19 August 1982 and 10 August 1988. The scale used in all maps is $1: 5000$.

The maps for 1973, 1982 and 1988, created by A. Ames, were produced by double-theodolite triangulation of a target rod held by a mobile collaborator, from precision-surveyed control points on rock outside the glacier (Fig. 2). These reference points are tied into the UTM coordinate system (Instituto Geográfico Militar, 1970, 1976). Contour spacing was $25 \mathrm{~m}$. From the roughness of the glacier surface, tolerance is estimated at about $10 \mathrm{~cm}$, although the surveying method yields a much higher precision.
The maps for 1962 and 1948 were produced by J. Scherz, University of Wisconsin-Madison, U.S.A. by stereo-photogrammetric analysis of historical vertical air photographs. The particulars for 17 June 1962 are AF-6017, M134, frames 15420 and 15421, indicated focal length $153.035 \mathrm{~mm}$. The details for 31 August 1948 are 457-88-B, frames 2524-866 and 2524-867, with the same focal length assumed. A compilation scale of 1:7812 and subsequent enlargement to scale 1:5000 was used with a contour interval of $25 \mathrm{~m}$. Tolerance is estimated at about $2 \mathrm{~m}$. As reference, four control points (Fig. 2) were available, determined in the coordinate system mentioned above. The 1962 map was compiled first, and supported by this the work for 1948 was undertaken. Coverage precluded mapping of the upper reaches of the glacier in 1948.

A major accomplishment of the mountaineering and scientific expeditions of the Deutsch-Österreichischer Alpenverein to the Cordillera Blanca in the 1930 s (Kinzl, 1942, 1949, 1964) was a first inventory and mapping of the glaciers. A result of this effort is a topographic map at scale $1: 100000$ based on terrestrial photogrammetry during May-August 1939. It proved possible to enlarge a part of this map to the $1: 25000$ scale of the official map sheet (Instituto Geográfico Militar, 1970 ), in order to identify prominent terrain features, and on this basis to transfer the 1939 boundaries of Yanamarey Glacier into the UTM coordinate system, with a tolerance of about $20 \mathrm{~m}$. The 1939 ice extent thus obtained is also shown in Figures 2 and 3.

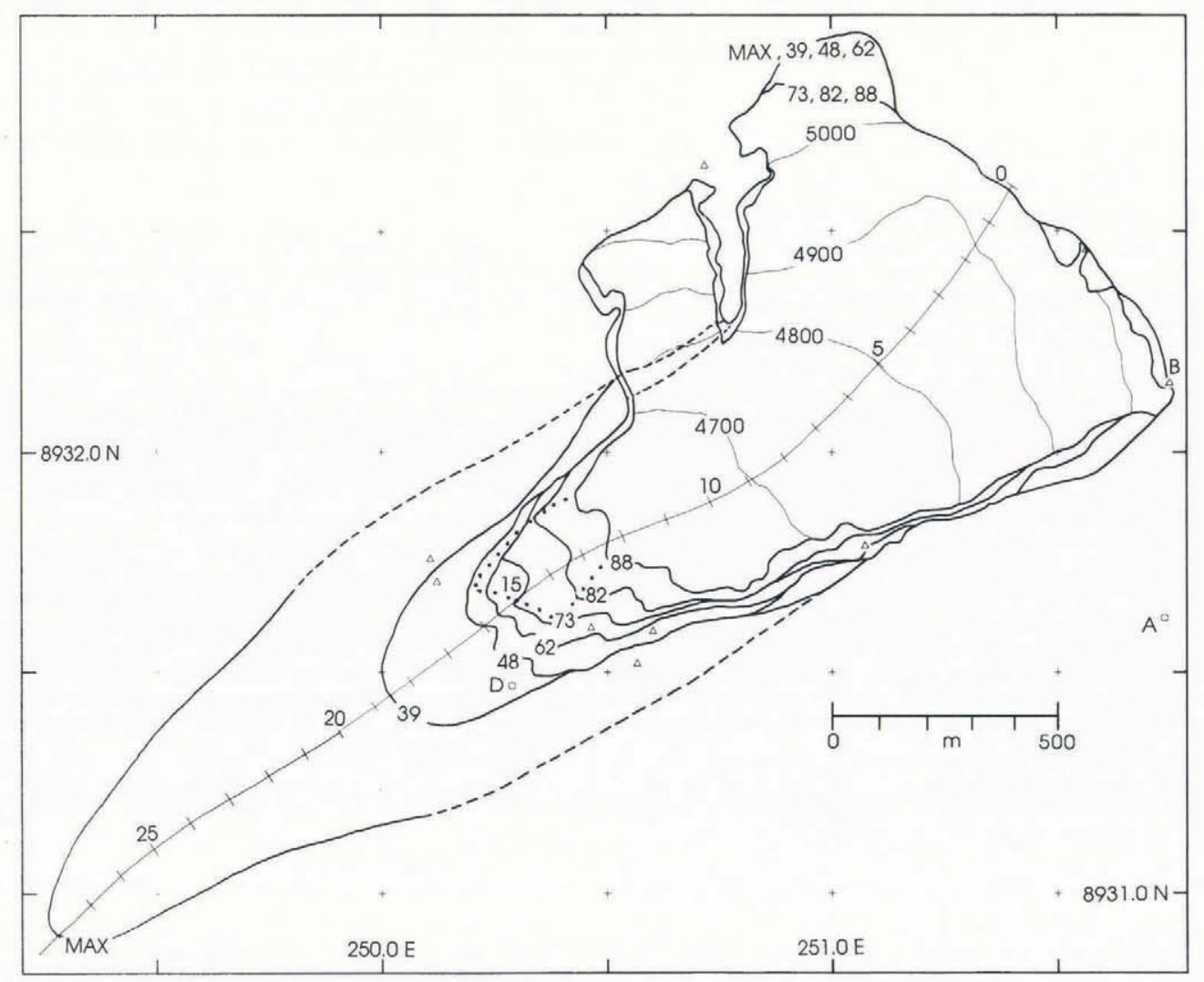

Fig. 2. Map showing the ice extent of Tanamarey Glacier to the maximum inferred from large moraines and for the dates May-August 1939, 31 August 1948, 19 June 1962, 10 May 1973, 19 August 1982 and 10 August 1988. Triangles indicate terrain-control points, and open circles the coordinated reference points used in the 1962 and 1948 maps. Contours at $100 \mathrm{~m}$ intervals are given for the 1988 status. 1988 extent of lake is shown by dotted line. Also entered is central longitudinal line with marks at $100 \mathrm{~m}$ spacing from upper edge of glacier (Fig. 3). Scale 1:20000. 


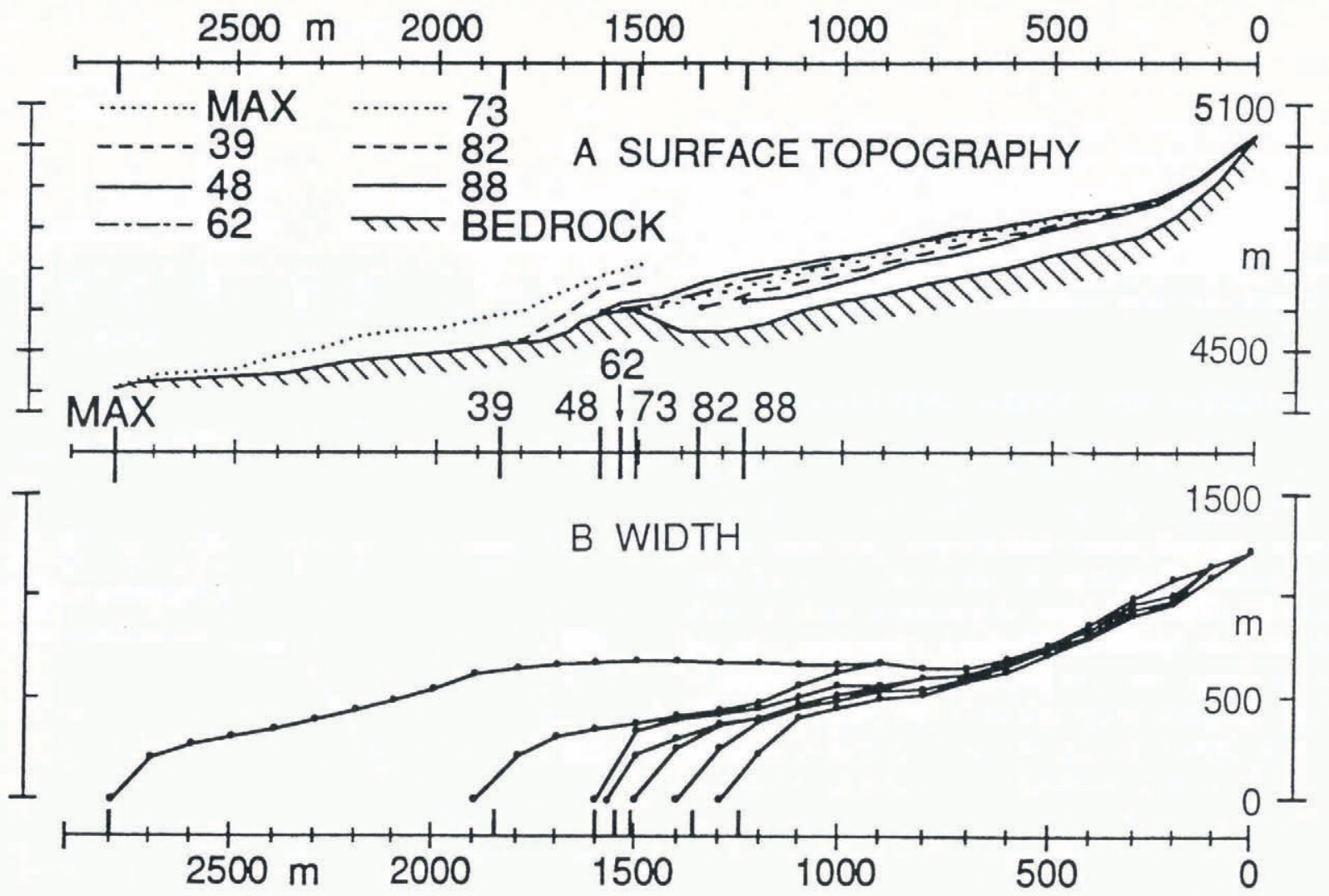

Fig. 3. Longitudinal profiles along central line shown in Figure 2; scale 1:20000. a. Longitudinal-vertical cross-section with no vertical exaggeration. Cross-hatching denotes bedrock; dotted, broken, solid, dash-dotted, dotted, broken and solid lines denote the ice surface topography for the maximum ice extent and 1939, 1948, 1962, 1973, 1982 and 1988, respectively. Vertical tick marks show terminus positions, including those for 1939 and the maximum extent. b. Glacier width plotted against distance from head, as measured along the lines passing through the equidistant points perpendicular to the central longitudinal line shown in Figure 1, for the maximum extent and 1939, 1948, 1962, 1973, 1982 and 1988, in m. Tick marks and labels on the middle horizontal scale indicate the terminus positions for these dates.

Finally, a maximum ice extent, without date, was determined from a system of large moraines that are prominent on air photographs (1962-63, AF-60-17: M132, 19 June 1962, frames 16701-16702; M163, 12 July 1962, frames 21094 21095; M337, 23 May 1963, frames 4107141072). Using identifiable terrain features for reference, these were transferred on to the existing 1:25000 sheet (Instituto Geográfico Militar, 1970) and thus into the UTM coordinate system, with a tolerance of about $20 \mathrm{~m}$. The maximum extent of the lower part of Yanamarey Glacier thus obtained is also shown in Figures 2-5.

\section{EVALUATION}

The diverse evidence described in section 2 needed to be evaluated in an internally consistent context. To that end, the maps for the various dates were brought into the same system of coordinates of the national map as indicated above. The entire information content of each of the 1988, 1982, and 1973 maps, namely coordinate system, control points, glacier boundary, and height contours as well as central longitudinal line with points at $100 \mathrm{~m}$ spacing (Figs 2 and 3), was digitally transferred to a database. The same was done for the 1962 and 1948 maps. For the epochs 1939 and "maximum extent" the input consisted of the ice boundary in the lower part of the glacier, together with the central line and equidistant points. The subsequent work could proceed digitally.

From the height contours, the surface topography was linearly interpolated on to a rectangular grid with $2 \mathrm{~m}$ spacing. Forming differences at each grid point gave the surface lowering between surveys, or the ice-thickness change.

The glacier was divided into $100 \mathrm{~m}$ wide bands, bounded by lines passing through the aforementioned equidistant points perpendicular to the central longitudinal line (Figs 2 and 3). Areas and area changes of these bands were evaluated digitally. Also, for these domains, the volume changes between surveys were determined by integrating the ice-thickness change over the respective areas.

Estimates of ice thickness, and thus volume, were obtained for the 1982 date. Essential for this was the bedrock topography along the central longitudinal line (Fig. 3a). This was available with a tolerance of about $10 \mathrm{~m}$ from numerical modeling to be detailed elsewhere in due course. Assuming a parabolic shape of the bedrock, the center-line depth and the observed width define the bedrock topography along the lines placed at $100 \mathrm{~m}$ intervals perpendicular to the central line. These values were digitized at $50 \mathrm{~m}$ spacing and then interpolated on to a rectangular grid with $2 \mathrm{~m}$ cell size as described above. Thickness changes for the $100 \mathrm{~m}$ wide bands were then evaluated digitally. 
For the 1939 date and for the maximum extent, ice thickness was estimated from the available topographic sheet (Instituto Geográfico Militar, 1970) as the difference in elevation between the center line and the ice margin. Estimates were made at equidistant center-line points down-glacier from the $1500 \mathrm{~m}$ longitudinal position. For the maximum position, the margin is marked by the lateral moraines. Ice thickness and volume for the $100 \mathrm{~m}$ wide bands were then evaluated as described above.

\section{CHANGES IN ICE EXTENT AND VOLUME}

The broadly southwestward-facing Yanamarey Glacier extends from its steep upper reaches above $5000 \mathrm{~m}$ to a terminus now well above $4600 \mathrm{~m}$. Since the early 1970 s the ice front has started to calve into a small lake contained behind an arc of moraines and a rock threshold. The glacier is now about $1 \mathrm{~km}$ long, with an area of less than $1 \mathrm{~km}^{2}$. An impression of the topography, from the mountain peaks behind to the valley below the glacier, is offered by Figure 3a. A complex of large moraines is taken as marking the "maximum extent" of the glacier, although other large moraine systems are found yet further down the valley as witnesses of earlier glacial events; these, however, will not be of concern here.

From a length of $2800 \mathrm{~m}$ at the maximum, the glacier had retreated to $1850 \mathrm{~m}$ by 1939 , with progressive further shrinkage in length and area during the subsequent intervals (Fig. 2). The changing ice-surface topography is illustrated in Figure 3a. From "maximum" to 1948, and again from 1948 to 1988 , the surface lowering exceeded $70 \mathrm{~m}$ in the lower part of the glacier. Accompanying the retreat of the glacier tongue from the "maximum" to 1939 was a massive decrease in the width and area (Fig. 2) in the lower part of the glacier (Fig. 3b). After 1948, the glacier was contained in a topographically more constrained domain, and accordingly the drastic thickness changes (Fig. 3a) were accompanied by comparatively moderate decreases in the width and area, primarily in the lower part of the glacier (Fig. 3b).

The longitudinal pattern of changes in area, thickness and volume between the survey dates is depicted in Figure $4 \mathrm{a}-\mathrm{c}$. For all three elements the decreases were most drastic near the progressively receding terminus. Thus, from "maximum" to 1939 and thence to 1948 area decreases were largest at longitudinal positions downglacier from $1300 \mathrm{~m}$, while during the subsequent time intervals the changes were concentrated between 1600 and $1300 \mathrm{~m}$. Decreases in thickness and volume are found to be largest somewhat further up-glacier, at longitudinal distances of $3000-1500 \mathrm{~m}$ during "maximum" to 1948 , and at $1300-700 \mathrm{~m}$ from 1948 to 1988 (Fig. 4b and c). Paralleling the progressive retreat of the glacier tongue, the largest thickness and volume changes tend to occur further up-glacier in later time intervals. Changes are generally small at longitudinal distances less than $500 \mathrm{~m}$.

Figure 5 presents the secular variations for the glacier as a whole. The ice volume (Fig. 5a) decreased by $35 \times 10^{6} \mathrm{~m}^{3}$ from "maximum" to 1948 ; by $22 \times 10^{6} \mathrm{~m}^{3}$ from 1948 to 1982 ; and by $7 \times 10^{6} \mathrm{~m}^{3}$ from 1982 to 1988 . From the information given in section 2, the error tolerances corresponding to these three time intervals

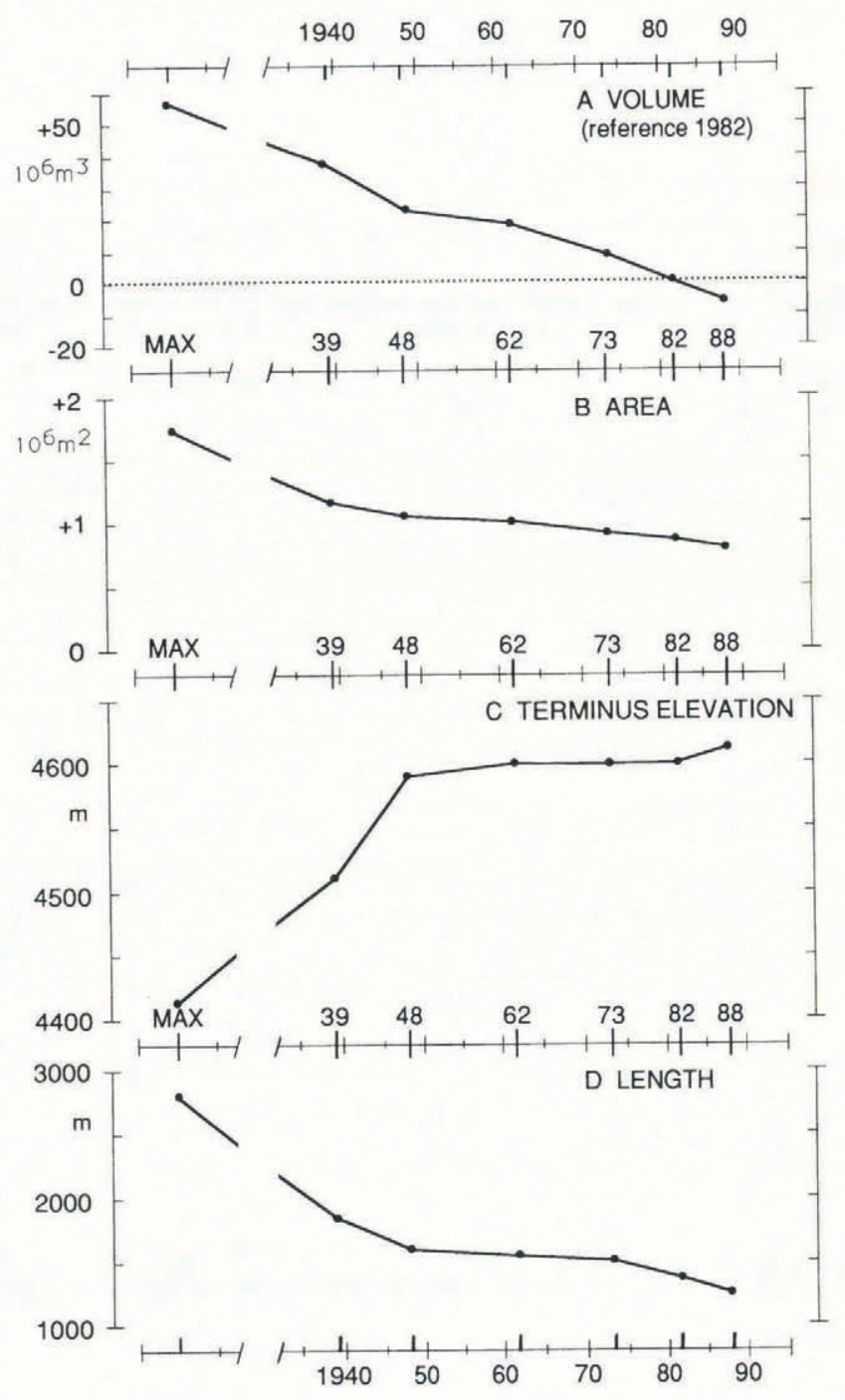

Fig. 5. Secular variation of Yanamarey Glacier. $a$. volume, measured relative to 1982 volume, which is estimated to be $32 \times 10^{6} \mathrm{~m}^{3}$. b. area. c. terminus elevation. d. length.

are estimated to decrease from $20 \times 10^{6}$ to $2 \times 10^{6}$ to $0.2 \times 10^{6} \mathrm{~m}^{3}$. From modeling, referred to in section 3 and to be detailed elsewhere in due course, the absolute ice volume of the entire glacier in 1982 is estimated to be $32 \times 10^{6} \mathrm{~m}^{3}$, with a tolerance of about $5-10 \times 10^{6} \mathrm{~m}^{3}$. The total area (Fig. 5b) is estimated to be $17 \times 10^{5} \mathrm{~m}^{2}$ for the maximum extent, compared to $8 \times 10^{5} \mathrm{~m}^{2}$ in 1988 . The terminus elevation (Fig. $5 \mathrm{c}$ ) changed by a large amount from maximum to 1939 , but then at a more rapid rate as a steep bedrock threshold was being passed. The length (Fig. 5d) also decreased substantially from the maximum to the 1988 conditions.

\section{CONGLUDING REMARKS}

As indicators of climatic change, variations of tropical glaciers are relevant in the global context. In this spirit, changes in the length and area of glaciers worldwide are now being regularly compiled and published in an international effort (Haeberli and Hoelzle, 1993). Although assessment of mass changes is needed for the study of the 


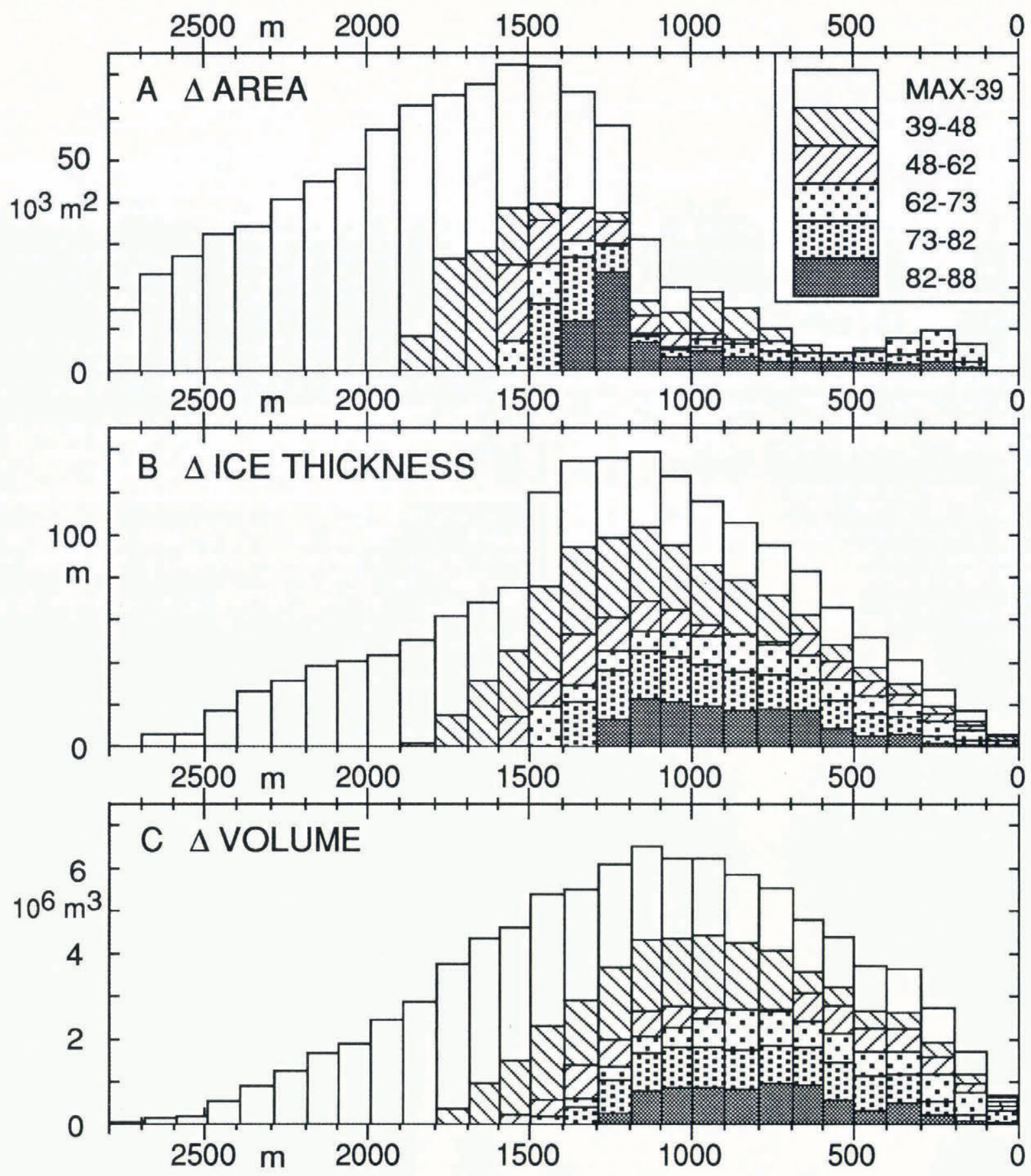

Fig. 4. Decreases over the time intervals maximum-1939, 1939 48, 1948 -62, 1962-73, 1973-82 and 1982 -88, for $100 \mathrm{~m}$ wide bands as defined in Figures 2 and 3. Horizontal scale 1:40000. a. Area. b. ice thickness. c. volume.

energy processes involved, even information on length and area changes is useful. Thus, assuming a priori an increase of air temperature as the sole cause of glacier retreat, Oerlemans (1994) used this data source to compute a corresponding atmospheric-warming rate. In a similar vein, Thompson and others (1993) interpreted ice-core records in terms of temperature change without consideration of ice-mass and energy processes. That forcings other than atmospheric warming may be instrumental is shown by numerical modeling of the ice dynamics, heat-budget sensitivity studies and diagnostics of secular circulation changes for the glaciers of East Africa (Kruss, 1984; Hastenrath and Kruss, 1992; Hastenrath, 1994).

With this motivation, Yanamarey Glacier was a target of opportunity for the assessment of volume change over much of this century. This is important because only changes in mass can properly be converted into energy equivalents in phase-change processes. Such information is rare especially for the tropical half of the Earth. The quantitative reconstruction of ice-mass changes presented here for Yanamarey Glacier serves as a basis for ongoing sensitivity analyses aimed at inferring the climatic forcing of the observed glacier shrinkage.

\section{ACKNOWLEDGEMENTS}

This study was supported by U.S. National Science Foundation grant No. EAR-9217211. At the University of Wisconsin, J. Scherz performed the stereo-compilation 
from the 1962 and 1948 air photography, and L. Greischar and D. Polzin assisted with the data processing and graphics. Comments by R. Hooke, L. Thompson and an anonymous reviewer on an earlier version of this paper are gratefully acknowledged.

\section{REFERENCES}

Allison, I. and P. Kruss. 1977. Estimation of recent climate change in Irian Jaya by numerical modeling of its tropical glaciers. Arct. Alp. Res., 9 (1), 49-60.

Ames, A. and 7 others. 1988. Inventario de glaciares del Perú. Huaraz, Unidad de Glaciología e Hidrología.

Brecher, H. H. and L. G. Thompson. 1993. Measurement of the retreat of Qori Kalis glacier in the tropical Andes of Peru by terrestrial photogrammetry. Photogramm. Eng. Remote Sensing, 59(6), 1017-1022.

Haeberli, W. and M. Hoelzle, comps. 1993. Fluctuations of glaciers 198590 (Vol. 6). Wallingford, International Association of Hydrological Sciences; Nairobi, United Nations Environment Programme; Paris, UNESCO.

Haeberli, W., E. Herren and M. Hoelzle, eds. 1993. Glacier mass balance bulletin. Bulletin No. 2 (1990-1991). Wallingford, International Association of Hydrological Sciences; Nairobi, United Nations Environment Programme; Paris, UNESCO.

Hastenrath, S. 1981. The glaciation of the Ecuadorian Andes. Rotterdam, Balkema.

Hastenrath, S. 1984. The glaciers of equatorial East Africa. Dordrecht, etc., D. Reidel Publishing Co.
Hastenrath, S. 1994. Recession of tropical glaciers. Science, 265, 1790-1791. Hastenrath, S. and P. D. Kruss. 1992. The dramatic retreat of Mount Kenya's glaciers between 1963 and 1987: greenhouse forcing. Ann. Glaciol., 16, 127-133.

Hope, G., U. Radok, J. A. Peterson and I. Allison. 1976. The equatorial glaciers of New Guinea: results of the 1971-1973 Australian Universities expeditions to Irian Jaya. Rotterdam, Balkema.

Instituto Geográfico Militar. 1970. Carta nacional 1:25,000. Hacienda Breque, hoja 20i-IV-SE. Lima, Instituto Geográfico Militar.

Instituto Geográfico Militar. 1976. Carta nacional 1:100,000. Recuay, hoja 20i. Lima, Instituto Geográfico Militar.

Kaser, G., A. Ames and M. Zamora. 1990. Glacier fluctuations and climate in the Cordillera Blanca, Peru. Ann. Glaciol., 14, 136-140.

Kinzl, H. 1942. Gletscherkundliche Begleitworte zur Karte der Cordillera Blanca (Peru). Z. Gletscherkd., 28(1/2), 1-19.

Kinzl, H. 1949. Die Vergletscherung in der Südhälfte der Cordillera Blanca (Peru). Z. Gletscherkd. Glazialgeol., 1(1), 1- 28.

Kinzl, H. 1964. Begleitwort zur Karte 1:100000 der Cordillera Blanca (Peru). Südteil. Wiss. Alpenvereinsh. 1.

Kruss, P. 1984. Climate change in East Africa: a numerical simulation from the 100 years of terminus record at Lewis Glacier, Mount Kenya. Z. Gletscherkd. Glazialgeol., 19 (1), 1983, 4360.

Oerlemans, J. 1994. Quantifying global warming from the retreat of glaciers. Science, 264, 243-245.

Schubert, C. 1992. The glaciers of the Sierra Nevada de Merida (Venezuela): a photographic comparison of recent deglaciation. Erdkunde, 46 (1), 58-64.

Thompson, L. G. and 6 others. 1993. "Recent warming": ice core evidence from tropical ice cores with emphasis on Central Asia. Global and Planetary Change, 7 (1-3), 145-156.

MS received 7 March 1994 and in revised form 7 July 1994 